Article (refereed) - postprint

Bonar, Scott A.; Mercado-Silva, Norman; Hubert, Wayne A.; Beard, T. Douglas; Dave, Göran; Kubečka, Jan; Graeb, Brian D.S.; Lester, Nigel P.; Porath, Mark; Winfield, Ian J.. 2017. Standard methods for sampling freshwater fishes: opportunities for international collaboration. Fisheries, 42 (3). 150-156. 10.1080/03632415.2017.1276352

(C) 2017 Informa UK Limited

This version available http://nora.nerc.ac.uk/516488/

NERC has developed NORA to enable users to access research outputs wholly or partially funded by NERC. Copyright and other rights for material on this site are retained by the rights owners. Users should read the terms and conditions of use of this material at http://nora.nerc.ac.uk/policies.html\#access

This is an Accepted Manuscript of an article published by Taylor \& Francis Group in Fisheries on 08/03/2017, available online:

http://www.tandfonline.com/loi/ufsh20 


\section{Standard Methods for Sampling Freshwater Fishes: Opportunities for}

\section{International Collaboration.}

\section{SCOTT A. BONAR ${ }^{1 *}$, NORMAN MERCADO-SILVA ${ }^{2}$, WAYNE A. HUBERT ${ }^{3}$, T.}

DOUGLAS BEARD JR. ${ }^{4}$, GÖRAN DAVE ${ }^{5}$, JAN KUBEČKA ${ }^{6}$, BRIAN D. S. GRAEB ${ }^{7}$; NIGEL

\section{P. LESTER $^{8} ;$ MARK PORATH $^{9}$, IAN J. WINFIELD $^{10}$}

7

${ }^{1}$ U. S. Geological Survey, Arizona Cooperative Fish and Wildlife Research Unit, 104 Biological Sciences East, University of Arizona, Tucson, Arizona, 85737, USA.

${ }^{2}$ Centro de Investigación en Biodiversidad y Conservación, Universidad Autónoma del Estado de Morelos; Cuernavaca, Morelos, México

${ }^{3}$ Department of Zoology and Physiology, University of Wyoming, 1000 E. University Avenue, Laramie, WY 82071, USA.

${ }^{4}$ U. S. Geological Survey, National Climate Change \& Wildlife Science Center, Reston, Virginia, USA.

${ }^{5}$ Department of Biology and Environmental Sciences, Göteborg University, Göteborg, Sweden.

${ }^{6}$ Institute of Hydrobiology, Biology Centre České Budějovice, Czech Republic.

${ }^{7}$ South Dakota State University, Natural Resource Management, Box 2140B, Brookings, South Dakota, 57007, USA.

${ }^{8}$ Ontario Ministry of Natural Resources 

2200 N 33rd Street, Lincoln, Nebraska, 68503, USA.

26 ${ }^{10}$ Lake Ecosystems Group, Centre for Ecology \& Hydrology,

27 Lancaster Environment Centre, Library Avenue, Bailrigg, Lancaster, Lancashire LA1 4AP,UK

28

29

30

31 *Corresponding Author: sbonar@ag.arizona.edu

32

33

34

35

36

37

38

39

40

41

42

43

44

45

46

47 

Fishes in 2009, the American Fisheries Society (AFS) recommended standard procedures for North America. To explore interest in standardizing at larger scales to improve communication

51 and collaboration with other continents, a symposium attended by international specialists in 52 freshwater fish sampling was convened at the $145^{\text {th }}$ Annual AFS Meeting in Portland, Oregon, 53 August, 2015. Participants represented all continents except Australia and Antarctica, and were 54 employed by state and federal agencies, universities, non-governmental organizations, and 55 consulting businesses. Currently, standardization is most practiced in North America and 56 Europe. Participants related how standardization has been important for management of long-

57 term data sets, furthering fundamental scientific understanding, and for testing efficacy of large 58 spatial scale management strategies. Academics indicated standardization has been useful in 59 fisheries education because time previously used to teach sampling method development is now 60 devoted to diagnosis and treatment of problem fish communities. Researchers reported 61 standardization allowed increased sample size for method validation and calibration. Group 62 consensus was to retain continental standards, but further explore international standardization, 63 specifically identifying where synergies and bridges exist; and identify means to collaborate with 64 scientists where standardization is limited, but interest and need occur. 
67 Efficient communication of data and findings across large areas is becoming increasingly

68 important. Issues such as climate change (IPCC 2014), widespread distribution of invasive

69 species (Fuller et al. 1999), and cross-boundary fish management strategies (Hubert and Quist

70 2010) are becoming too large to only be considered on a local level for effective understanding

71 and management. Furthermore, generally reduced budgets for programs and the need to increase

72 sample sizes to meet statistical needs to test management strategies have made collaboration

73 among different fisheries programs important. The ability to compare data over time and

74 throughout areas, via standard sampling, standard indices and standard comparison methods, has

75 revolutionized many areas of fish and fisheries science, such as baseline knowledge of fish

76 populations and ecology (Swingle 1950; Argillier et al. 2012; Emmrich et al. 2012; Jeppesen et

77 al. 2012; Brucet et al. 2013; Emmrich et al. 2014; Arranz et al. 2015), conservation and

78 management of inland fish (Åslund and Degerman 2007; Winfield et al. 2008; Holmgren and

79 Fölster 2010; Winfield et al. 2012; Winfield et al. 2013), and fisheries education (B. Graeb,

80 South Dakota State University and I. Winfield, Lake Ecosystems Group, Centre for Ecology and

81 Hydrology, paper presented at AFS symposium, 2015). Conversely, the inability to compare

82 non-standardized data at large scales and over time has resulted in difficulty in fisheries

83 planning, monitoring population and community trends, and having enough samples to make

84 useful conclusions (Vostradovsky and Tichy, 1999; G. Whelan, Michigan Department of Natural

85 Resources, paper presented at AFS symposium, 2015).

Because of the improved benefits to fisheries biologists, the scale at which

87 standardization has occurred is steadily increasing as is evident from the chronology of the

88 exemplar studies cited above. Historically, in the U.S., Canada and Europe standardization only

89 occurred at state or local levels. However, today continent-wide standards for fish sampling 
90 have been developed and are being increasingly adopted (e.g., CEN 2003, 2006, 2014, 2015;

91 Bonar et al. 2009; European Commission 2015). In other regions of the world, sampling

92 standardization is carried out at vary small scales, and is incipient (Mercado-Silva and Bonar 93 2013).

Recently, the standardization committee of the Fisheries Management Section (FMS) of

95 the American Fisheries Society (AFS) was tasked with investigating the feasibility of comparing

96 standard data (i.e. data collected in one way so comparisons can be easily made) at an

97 intercontinental scale. The overall goal of the Section was to convene a symposium to: (1)

98 identify the extent of standard inland fisheries sampling programs in different regions of the

99 world; (2) present examples of how standard sampling programs, if present, are currently being

100 used; (3) organize a facilitated discussion among participants to investigate if and how AFS

101 could engage in the development of international inland fish standard sampling programs, and if

102 so, devise how participants in various programs might collaborate in the future. This information

103 would be aggregated into a report of recommendations to the AFS. Here we report the findings

104 from the symposium, and discuss future directions in standard sampling efforts identified by

105 attendees of the discussion section.

106

$107<$ A $>$ Methods

108 A two-day symposium was planned by the AFS Fisheries Management and AFS

109 International Fisheries Sections within the $145^{\text {th }}$ Annual Meeting of the AFS in Portland, Oregon,

110 in August 2015. An international planning committee consisting of leaders of North American

111 and European standard sampling programs was tasked with selecting speakers. Speakers from

112 each continent, or in some instances subcontinents, who were familiar to the committee as inland 
113 fish sampling experts, were invited. Speakers represented the following regions: North America, 114 Mesoamerica, South America, Europe, South East Asia, and Africa. Representatives from 115 Australia, Russia and Central Asia were invited but could not attend.

116 During the first day and the first half of the second day of the symposium presenters 117 discussed a variety of subjects related to standardization. An initial set of speakers described the 118 extent of fisheries standard sampling programs in different regions of the globe. Their talks 119 included discussions of process with which standards, if they existed, were developed and 120 reviewed, and a description of the main users of inland fisheries data in their regions. A second set of speakers who were familiar with established standard sampling programs 122 discussed advances in standard sampling, and how advances in gear and data collection strategies 123 were being employed in these programs. Benefits of standard sampling in management, research 124 and education were identified; and disadvantages of not standardizing were also presented. During the second half of the second day, a facilitated discussion was conducted in a 126 structured decision-making (SDM) format (Hammond et al. 1999) to identify future directions of 127 AFS in collaborating with other continents on standard sampling methods. SDM has been 128 increasingly adopted as a powerful method to facilitate acquisition of information originated in 129 environmental management discussions, which often face multidimensional choices guided by 130 uncertain science, diverse stakeholders and difficult trade-offs (Hammond et al. 1999; Gregory et 131 al. 2012). To guide the discussion, a PowerPoint (Microsoft, Inc.) presentation was prepared that 132 incorporated real-time voting (Turning Technologies, Youngstown, Ohio) to prepare a 133 contingency table ranking objectives and alternatives (Hammond et al. 1999). Participants in the 134 SDM session had electronic vote recorders assigned to them, and each responded to a series of 135 questions to 1) identify characteristics about the sampling frame of the participants, 2) identify 
their preferences related to standard sampling and 3) deliberate ideas concerning future directions of standard sampling. Prior to initiating the discussion section, the SDM process was explained to the audience, vote recorders were tested and voting procedures were rehearsed. The first questions asked of the SDM participants included demographic information. They were asked if a) they were AFS members, b) on which continent the majority of their sampling occurred, c) what type of job they held (management, research, administration, etc.); and d) the type of organization (non-governmental, governmental, education, etc.) for which they worked.

Next the participants were tasked with developing a consequences table for answering the following overall question: "Should AFS work with biologists on other continents to standardize inland fish sampling, and if so, how?" To achieve this goal, participants were first asked to identify elements of a successful standard sampling program (e.g., low cost, high precision and accuracy, ability to validate, etc.). Elements were discussed and those deemed similar by all participants were combined until a list of 10 was obtained. These 10 elements were then ranked by the participants (top three elements selected by each participant) to weight them by importance. Elements and their corresponding weights were entered into the left column of a consequences table (Table 1). Next, participants were queried as to alternative actions that would best address the elements of a successful standard sampling program. Actions were also discussed, and fine-tuned if necessary. Actions were placed across the top row of the table (see Table 1).

To complete the table, each action was ranked by electronic anonymous voting by the participants as to how well it would satisfy each element of a successful standard sampling program. Ranks were identified and entered into the consequences table, with the highest-ranked 
159 action for a particular element having the highest number. The rank of each action was then

160 multiplied by the weight of each corresponding element to provide a weighted rank. Weighted

161 ranks for each action were then summed to identify the participants' preferred action.

162

163

$<\mathrm{A}>$ Results and Discussion

Twenty-two talks were presented at the symposium and the number of attendees varied between 20-60 participants per talk (Mean [SD] = 36[9]). Twenty-seven participants were involved in the final discussion. The degree of standardization by continent varied considerably.

167 North American methods were standardized through the American Fisheries Society. These 168 methods were developed by waterbody type (large standing water, small standing water, large 169 river, wadeable stream, two-story system) for both cold and warm water fish species (Bonar et al. 170 2009). Methods were developed and reviewed through input from 284 biologists from 107 171 different agencies and organizations from across North America. European methods were 172 standardized by CEN/TC230/WG2(“015) of the European Committee for Standardization 173 (CEN/TC230/WG2 2015). With the exception of one standard on method selection (CEN 174 2006), methods from Europe have been developed by individual gear type for electrofishing 175 (CEN 2003), mobile hydroacoustics (CEN 2014) and gill netting (CEN 2015) with the latter 176 being a formal revision of a standard first published in 2005. In Southeast Asia, standardization 177 occurs in large areas systems such as the Mekong River and is implemented via commercial 178 fishery catch data. Standardization of inland fish sampling is currently either non-existent or 179 localized and incipient in South America, Africa, and much of Mesoamerica. We cannot report 180 reliably to the extent of current inland fish standardization across central and northern Asia, east 181 Asia and Australia. Such presentations showed that gears strongly vary across regions and 
182 continents and highlighted observed barriers and limitations for developing standardized 183 sampling procedures.

Biologists who had undertaken standardized inland fish sampling for years identified real

185 benefits to standardizing on large scales. For example, thousands of acidified rivers and lakes 186 are managed by regular spread of limestone in Swedish watersheds (Svenson et al. 1995), and 187 standard electrofishing and sampling with multi-mesh gillnets was used over a multi-decade 188 period to identify improvements to the fish populations at a national scale in streams and lakes, 189 respectively (e.g. Åslund and Degerman 2007, Holmgren and Fölster 2010). Similarly, continent190 wide effects of climate change on lake fish populations and the complicating effects of 191 widespread eutrophication have only been detectable because of the common approach to 192 monitoring now adopted by European countries (Jeppesen et al. 2012). The application of 193 standardized sampling methods led to the intercalibration of ecological quality and integrity of 194 fish communities across Europe (Ritterbush et al, 2015). In Argentina, standardization has been 195 useful in providing a broad picture of fish resources at large spatial scales when samplings were 196 time-restricted (L.G.M. Silva, C. Baigun, Instituto Tecnológico de Chascomus, Argentina, and P. 197 Pompeu, Universidade Federal de Lavras, Brazil, paper presented at AFS symposium, 2015). 198 Education of fisheries students at universities improved with increased method standardization 199 because more time could be spent in fisheries classes diagnosing problems in fish populations 200 versus time spent on method development (e.g., Graeb and Winfield, unpublished). Conversely, 201 lack of standardization hindered data comparisons within large scale initiatives such as the Fish 202 Habitat Partnership in the United States (Whelan, unpublished). Scientists at the symposium identified further work with standardization that might be of 204 highest priority. Speakers noted that a process to incorporate advancements in electrofishing, 
various forms of netting, hydroacoustics and other established techniques, and those not yet widely used (e.g., environmental DNA, videography) should be included in future updates of

207 documents describing or regulating standard sampling methods (numerous authors at

208 symposium). Further validation and calibration of methods was also identified as an area

209 needing further work (J.T. Peterson, USGS Oregon Cooperative Fish and Wildlife Research

210 Unit, C.P. Paukert, and A. Rosenberger, USGS Missouri Cooperative Fish and Wildlife Research

211 Unit, and S.K. Brewer, USGS Oklahoma Cooperative Fish and Wildlife Research Unit, paper

212 presented at AFS symposium, 2015). Increasing standardization means that fewer techniques

213 need to be ground-truthed to actual population parameters and calibrated to other standard

214 sampling methods. This results in a higher sample size for calibrating and validating, with

215 associated higher precision and accuracy. Further, focusing on the power standardization can

216 give ground-truthing measures to actual population parameters was identified as an important

217 benefit. Standard procedures in data collection are similarly important when comparing data and

218 such procedures, when combined with standard gear deployment, provide the most and best

219 quality information (A. Loftus, Loftus Consulting; D. Austen, American Fisheries Society, and

220 S.A. Bonar, USGS Arizona Cooperative Fish and Wildlife Research Unit, paper presented at

221 AFS symposium, 2015).

222 The SDM session helped identify areas AFS should prioritize to further sampling method 223 standardization internationally. The majority of the participants in the SDM session were AFS 224 members, and conducted freshwater fisheries work primarily in North America, although some 225 conducted their work primarily in South America, Europe, and Africa (Figure 1). The greatest 226 percentage of participants were from universities, although state and federal agencies, 
227 consultants, and non-governmental organizations were all represented. Participants ranged from

228 University researchers to students, research biologists, administrators and others (Figure 1).

A list of 10 elements valuable for ranking standard sampling programs, and how well

230 expanding programs beyond continental borders would benefit the profession, was successfully

231 developed by the participants. Highest ranked elements of a standard sampling program that

232 would best benefit the profession included developing methods that could be applied with the

233 highest accuracy, consistency and precision; a program that had the greatest probability of being

234 adopted by users; and a program that was biologically broadly applicable and applicable to the

235 widest set of goals (Table 1).

Considering the elements identified above, discussion participants identified a series of

237 alternatives related to AFS involvement in international standardization efforts: international bodies (e.g. Food and Agriculture Organization of the United Nations, World Council of Fisheries Societies) to investigate need and enthusiasm for international standards; C. AFS would continue to use existing standards, but will facilitate synergies/bridges, crosswalks, and intercalibration of existing methods for standardization to recommend to the

244 international community;

246 standards, and (ii) communicate with international bodies to investigate need for international

247 standards. If need is found then (iii) AFS would examine where synergies/bridges exist (iv)

248 secure funding to develop intercalibration among areas and in collaboration with other groups to

249 help design methods for locations where there is not standardization; 
E. AFS would work with others to develop an entire new set of international standards in

251 lieu of existing standards;

F. AFS would encourage continental standards (suitable for different continents), then explore synergies for international standardization.

Clear support existed among the SDM participants for AFS to engage the international

255 community on standard sampling (Table 1). However, participants were not in favor of

256 developing new international standards in lieu of existing continental standards. Retaining

257 existing continental standards and examining opportunities to identify synergies, bridges and

258 "crosswalks" among standard sampling methods from different continents was favored. In

259 addition participants favored supporting other continents which had not yet developed standard

260 procedures; however, residents of those continents would need to take the lead in developing

261 standard procedures or at least request the help from AFS or international bodies.

A move toward finding bridges among continental standardization programs would

263 provide many benefits. Fish communities and species ecological features within a continent are

264 largely similar and standardization at this (or lower) scale is very important. However,

265 intercontinental comparability may be less often required. As one participant suggested, there

266 are few times biologists would need to compare a population of fish in a lake in the United

267 Kingdom with one in Central Africa. However, intercontinental standardization would have

268 value in specific cases, such as for closely related species (e.g., yellow perch Perca fluviatilis

269 and Eurasian perch Perca flavescens) or species found on multiple continents (e.g. common carp

270 Cyprinus carpio) and for invasive species which spread across multiple continents (e.g.

271 mosquitofish Gambusia affinis). Furthermore, a general awareness of international

272 standardization is of value, especially for new sampling and monitoring programs in the areas 
273 where no standards are available. Collaboration among continents could also help define

274 minimal requirements to be set on all continents, provide recommendations for new methods

275 having no local standards, promote methods that participants agree are clearly better than others,

276 examine worldwide factors affecting fish and fisheries (e.g., climate change), and assist countries

277 or continents that have no current standards to develop them.

278 In summary, consensus of symposium participants was that the AFS led a very important

279 process in North America to improve fish sampling methods but there is a need to collaborate

280 with biologists on other continents during continued development of standard inland fish

281 sampling programs. Continental standards should be retained, but biologists should look for

282 bridges and synergies among them, such developing as common methods to sample species

283 found on multiple continents, or intercalibration of specific methods. A potential result of such

284 collaboration and methods standardization in other continents when different but common

285 fishing gears are used, could be the publication of specific guidelines to reinforce and support the

286 need to use standard assessments. Those already using continental standards should help

287 developing nations develop standards where needed. 
$<\mathrm{A}>$ References

Argillier, C., S. Caussé, M. Gevrey, S. Pédron, J. De Bortoli, S. Brucet, M. Emmrich, E. Jeppesen, T. Lauridsen, T. Mehner, M. Olin,M. Rask, P. Volta, I. J. Winfield, F. Kelly, T. Krause, A. Palm, and K. Holmgren. 2012. Development of a fish-based index to assess the eutrophication status of European lakes. Hydrobiologia 704:193-211.

Arranz, I., T. Mehner, L. Benejam, C. Argillier, K. Holmgren, E. Jeppesen, T. L. Lauridsen, P. Volta, I. J. Winfield, and S. Brucet. 2015. Density-dependent effects as key drivers of intraspecific size structure of six abundant fish species in lakes across Europe. Canadian Journal of Fisheries and Aquatic Sciences. dx.doi.org/10.1139/cjfas-2014-0508.

Åslund, J.-Å., and E. Degerman. 2007. Kalkning av försurade vatten i Jämtlands län 1983-2006 - effecter på fiskfaunan i strömmande vatten. Länsstyrelsen i Jämtlands län, Rapport 2007:2. (In Swedish)

Bonar, S. A., W. A. Hubert, and D. W. Willis, editors. 2009. Standard methods to sample North American freshwater fishes. American Fisheries Society, Bethesda, Maryland.

Brucet, S., S. Pédron, T. Mehner, T. L. Lauridsen, C. Argillier, I. J. Winfield, P. Volta, M. Emmrich, T. Hesthagen, K. Holmgren, L. Benejam, F. Kelly, T. Krause, A. Palm, M. Rask and E. Jeppesen. 2013. Fish diversity in European lakes: geographical predictors dominate over anthropogenic pressures. Freshwater Biology 58:1779-1793. 
312 CEN (European Committee for Standardization). 2003. European Standard EN 14011:2003.

313

314

315

316

317

318

319

320

321

322

323

324

325

326

327

328

329

330

331

332

333
Water quality - sampling of fish with electricity. European Committee for

Standardization, Brussels, Belgium.

CEN (European Committee for Standardization). 2006. European Standard EN 14962:2006.

Water quality - guidance on the scope and selection of fish sampling methods. European Committee for Standardization, Brussels, Belgium.

CEN (European Committee for Standardization) 2014. European Standard EN 15910:2014. Water quality - Guidance on the estimation of fish abundance with mobile hydroacoustic methods. European Committee for Standardization, Brussels, Belgium.

CEN (European Committee for Standardization). 2015. European Standard EN 14757:2015. Water quality - sampling of fish with multi-mesh gillnets. European Committee for Standardization, Brussels, Belgium.

CEN/TC230/WG2 (Water Analysis. Biological Methods Co-Ordination Group). 2015. Biological Methods Co-Ordination Group. European Committee for Standardization, Brussels, Belgium. Available: http://standards.cen.eu/dyn/www/f?p=204:32:0:.::FSP_ORG_ID,FSP_LANG_ID:7562,2 $\underline{\text { 5\&cs=1BC5CC04CDF942A3C83B07E131CD4B9D5 }}$ (December 2015). 
Emmrich, M., I. J. Winfield, J. Guillard, A. Rustadbakken, C. Vergés, P. Volta, E. Jeppesen, T. L. Lauridsen, S. Brucet, K. Holmgren, A. Argillier, and T. Mehner. 2012. Strong correspondence between gillnet catch per unit effort and hydroacoustically derived fish biomass in stratified lakes. Freshwater Biology 57:2436-2448.

Emmrich, M., S. Pédron, S. Brucet, I. J. Winfield, E. Jeppesen, P. Volta, C. Argillier, T. L. Lauridsen, K. Holmgren, T. Hesthagen, and T. Mehner. 2014. Geographical patterns in the size structure of European lake fish communities along abiotic and biotic gradients. Journal of Biogeography 41:2221-2233.

European Commission, 2015. The EU Water Framework Directive - Integrated river basin management for Europe. European Commission, Brussels, Belgium. Available: http://ec.europa.eu/environment/water/water-framework/index_en.html. (December 2015).

Fuller, P. L., L. G. Nico, and J. D. Williams. 1999. Nonindigenous fishes introduced into inland waters of the United States. American Fisheries Society, Special Publication 27, Bethesda Maryland.

Gregory, R., L. Failing, M. Harstone, G. Long, T. McDaniels, and D. Ohlson. 2012. Structured Decision Making; a practical guide to environmental management choices. Wiley. Hoboken, New Jersey. 
Hammond, J. S., R. L. Keeney, and H. Raiffa. 1999. Smart choices: A practical guide to making better decisions. Crown Business, New York.

Holmgren, K., and J. Fölster. 2010. Biologisk och vattenkemisk variation i kalkningsverksamhetens målsjöar - ett förbättrat underlag för bedömning av IKEUsjöarnas representativitet. Institutionen för vatten och miljö, SLU. Rapport 2010:11 (In Swedish).

Hubert, W. A., and M. C. Quist, editors. 2010. Inland fisheries management in North America, $3^{\text {rd }}$ Edition. American Fisheries Society, Bethesda, Maryland.

IPCC (Intergovernmental Panel on Climate Change). 2014. Summary for Policymakers. In: Climate Change 2014: Impacts, Adaptation, and Vulnerability. Part A: Global and Sectoral Aspects. Contribution of Working Group II to the Fifth Assessment Report of the Intergovernmental Panel on Climate Change. Pages 1-32 in C. B. Field, C. B., V. R. Barros, D. J. Dokken, K. J. Mach, M. D. Mastrandrea, T. E. Bilir, M. Chatterjee, K. L. Ebi, Y. O. Estrada, R. C. Genova, B. Girma, E. S. Kissel, A. N. Levy, S. MacCracken, P. R. Mastrandrea, and L. L. White, editors.. Cambridge University Press, Cambridge, United Kingdom and New York, USA. 
377

378

379

380

381

382

383

384

385

386

387

388

389

390

391

392

393

394

395

396

397

398

399

Jeppesen, E., T. Mehner, I. J. Winfield, K. Kangur, J. Sarvala, D. Gerdeaux, M. Rask, H. J. Malmquist, K. Holmgren, P. Volta, S. Romo, R. Eckmann, A. Sandström, S. Blanco, A. Kangur, H. Ragnarsson Stabo, M. Tarvainen, A. -M. Ventelä, M. Søndergaard, T. L. Lauridsen, and M. Meerhoff. M. 2012. Impacts of climate warming on the long-term dynamics of key fish species in 24 European lakes. Hydrobiologia 694:1-39.

Mercado-Silva, N. and S.A. Bonar. 2013. Estandarización de métodos para el muestreo de peces de agua dulce en México: Avances y oportunidades. Revista Ciencia Pesquera 21(2):5763.

Ritterbusch, D., Argillier, C., Arle, J., Białokoz, W., Birzaks, J., Blabolil, P., Breine, J., Draszkiewicz-Mioduszewska, H., Jaarsma, N., Karottki, I., Krasucka, S., Krause, T., Kubečka, J., Lauridsen, T., Logez, M., Maire, A., Palm, A., Peirson, G., Poikane, S., Ř́ha, M., Szlakowski, J., Virbickas T., 2015. Central Baltic Lake Fish Intercalibration Group. Results of the Intercalibration Process 2013-2015. Report for EU ECOSTAT.

Svenson, T., W. Dickson, J. Hellberg, G. Moberg, and N. Munthe. 1995. The Swedish liming programme. Water, Air and Soil Pullution 85:1003-1008.

Swingle, H. S. 1950. Relationships and dynamics of balanced and unbalanced fish populations. Agricultural Experiment Station of the Alabama Polytechnic Institute, Bulletin Number 274, Auburn, Alabama 
400

401

402

403

404

405

406

407

408

409

410

411

412

413

414

415

416

417

418
Vostradovsky, J. and J. Tichy. 1999. History of fish stock development, fishery management and research on the Lipno reservoir [Czech Republic]. Bulletin VURH Vodnany (Czech Republic) 35:48-65.

Winfield, I. J., J. M. Fletcher, and J. B. James. 2008. The Arctic charr (Salvelinus alpinus) populations of Windermere, U.K.: population trends associated with eutrophication, climate change and increased abundance of roach (Rutilus rutilus). Environmental Biology of Fishes 83:25-35.

Winfield, I. J., C. E. Adams, C. W. Bean, N. C. Durie, J. M. Fletcher, A. R. Gowans, C. Harrod, J. B. James, A. A. Lyle, P. S. Maitland, C. Thompson, and E. Verspoor. 2012. Conservation of the vendace (Coregonus albula), the U.K.'s rarest freshwater fish. Advances in Limnology 63:547-559.

Winfield, I. J., Bean, C. W., Gorst, J., Gowans, A. R. D., Robinson, M. \& Thomas, R. 2013. Assessment and conservation of whitefish (Coregonus lavaretus) in the U.K. Advances in Limnology 64:305-321. 
$<\mathrm{A}>$ Acknowledgements

We thank the AFS Fish Management Section for supporting standardization efforts

across North America including the AFS standard sampling book, a webtool to compare standard sampling data, and the international standard sampling symposium. Other organizations such as

424 the AFS International Fisheries Section, the U.S. Geological Survey Climate Change Program 425 and Cooperative Fish and Wildlife Research Programs, Hydroacoustic Technology Incorporated and ETS Electrofishing Systems also partnered with the Section to contribute to this symposium.

427 We thank collaborators from five continents who participated in providing data and opinions or 428 presenting presentations given at the symposium in addition to the authors of this publication.

429 They were: Diego Elias, Southeastern Louisiana University; Leticia Huidobro Campos, Instituto 430 Nacional de la Pesca, Mexico; Arturo Angulo Sibaja, Universidad de Costa Rica; Aldo Farah 431 Pérez, Universidad de Costa Rica; Christian Barrientos, Universidad de San Carlos de 432 Guatemala; Luiz G. M. Silva, UFSJ, Brazil; Claudio Baigun, Instituto Tecnológico de 433 Chascomus (CONICET-UNSAM), Argentina; Paulo Pompeu, Universidade Federal de Lavras, 434 Brazil; Nam So, Mekong River Commission, Cambodia; Kerstin Holmgren, Björn Bergquist, 435 Erik Degerman, Anders Kinnerbäck, and Thomas Axenrot, Swedish University of Agricultural 436 Sciences; Gary Whelan, Michigan DNR Fisheries Division; James B. Reynolds, University of 437 Alaska Fairbanks; Marie Prchalova, Petr Blabolil, Roman Baran, Marek Smejkal, Milan Riha, 438 Tomas Juza, Jaroslava Frouzova, Michal Tuser, Biology Centre CAS v.v.i., Institute of 439 Hydrobiology, Czech Republic; Mika Kurkilahti, Natural Resources Institute Finland; Mikko 440 Olin, University of Helsinki, Finland; Daniel E. Shoup, Oklahoma State University; Maureen G. 441 Walsh, USGS Great Lakes Science Center; Daniel L. Yule, USGS Great Lakes Science Center; 
442 David M. Warner, USGS Great Lakes Science Center; Jean Guillard, INRA, UMR Carrtel;

443 Malgorzata Godlewska, European Regional Centre for Ecohydrology, Polish Academy of

444 Sciences; Helge Balk, University of Oslo, Norway; Lars G. Rudstam, Cornell Biological Field

445 Station, Cornell University; Sally Petre, Arizona Game and Fish Department; Jon J. Amberg,

446 Christopher Rees, U.S. Geological Survey; Morgan Brizendine, Christina Perez, Jack E.

447 Ruggirello, Roy Ulibarri, University of Arizona; Scott A. Bonar, U.S. Geological Survey

448 Arizona Cooperative Fish and Wildlife Research Unit; Ambre Chaudoin, Great Basin

449 Institute/U.S. Fish and Wildlife Service; Olin Feuerbacher, U.S. Fish and Wildlife Service;

450 James T. Peterson, U.S. Geological Survey Oregon Cooperative Fish and Wildlife Research

451 Unit; Craig P. Paukert, Amanda Rosenberger, U.S. Geological Survey Missouri Cooperative Fish

452 and Wildlife Research Unit; Shannon K. Brewer, U.S. Geological Survey Oklahoma Cooperative

453 Fish and Wildlife Research Unit; George Morgan, Laurentian University; Peter Addison, Ontario

454 Ministry of Natural Resources and Forestry; Allan Bell, Steve Sandstrom, Ontario Ministry of

455 Natural Resources; Lorraine Brekke, Cooperative Freshwater Ecology Unit, Laurentian

456 University; Mark Scott, Kevin Kubach, South Carolina Department of Natural Resources;

457 Yoichiro Kanno, Kasey Pregler, Clemson University; Bradley Smith, Melissa Wuellner, David

458 W. Willis, South Dakota State University; Brian Blackwell, South Dakota Game, Fish and Parks;

459 Stephen Tyszko, Matt Hangsleben, Richard D. Zweifel, Ohio Division of Wildlife; Jeff Koch,

460 Kansas Department of Wildlife, Parks, and Tourism; Bill Wentroth, Oklahoma Department of

461 Wildlife Conservation; Andrew Loftus, Loftus Consulting; Douglas Austen, American Fisheries

462 Society; Dorothy Wanja Nyingi, National Museums of Kenya; Henry L. Bart Jr., Ray C.

463 Schmidt, Tulane University; Olivier Hamerlynck, National Museums of Kenya; Nathan Ndegwa

464 Gichuki, University of Nairobi, Kenya; Mordecai Ogada, Conservation Solutions Afrika, Kenya. 
Table 1. Consequences table for a structured decision making (SDM) session held at the international standard sampling symposium to decide how the American Fisheries Society should proceed in fomenting standard sampling methods internationally. Elements of a successful standard sampling program, and action alternatives to best address these elements were developed by the participants. Importance of different elements was defined by weights assigned by the participants. The audience then voted on how well each action alternative met each element, by ranking (Rank) them from highest to lowest (e.g., $6=$ best, $1=$ worst). Weights were

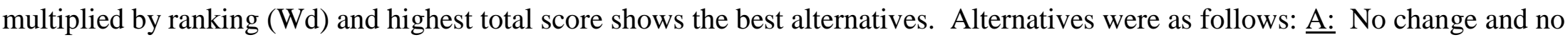
coordination among continents; $\underline{B}$ : AFS uses existing standards, but AFS communicates with international bodies (FAO, WCFS) to investigate need and enthusiasm for international standards; C: AFS uses existing standards, but facilitates synergies/bridges, crosswalks, intercalibration of existing methods for standardization to recommend to the international community; $\underline{\mathrm{D}}$ : AFS works in a series of steps. We (1) use existing AFS standards, (2) communicate with international bodies to investigate need for international standards. If need is found we then (3) examine where synergies/bridges exist (4) secure funding to develop intercalibration among areas and in collaboration with other nations, help design methods for locations where there is not standardization; E: AFS works with others to develop an entire new set of international standards in lieu of existing standards; $\underline{F}$ : AFS to encourage continental standards (suitable for these different continents), then explore synergies for international standardization. 


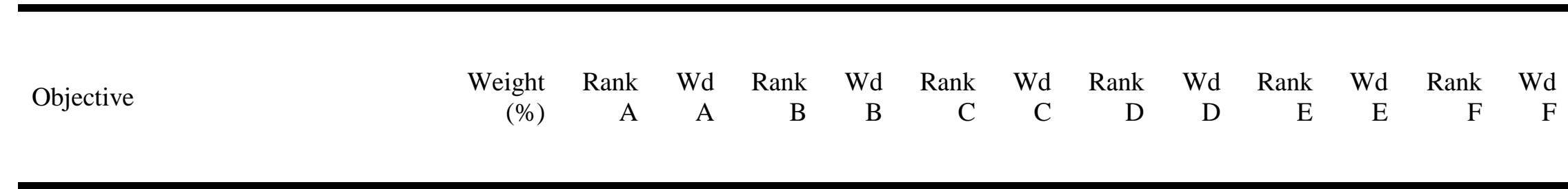

Greatest probability of being

adopted by users

$\begin{array}{llllllllllll}2 & 30 & 6 & 90 & 3 & 45 & 5 & 75 & 2 & 30 & 5 & 75\end{array}$

Comparability to past and future

methods

$12 \quad 1 \quad 12$

$3 \quad 36$

50

Highest accuracy, consistency and precision

21

21

3

63

5105

242

$5 \quad 105$

Validated, known sources and sizes

of bias

9

(1)

(2)

Affordable, cost effective and feasible

$\begin{array}{llll}7 & 1 & 7 & 4\end{array}$


Biologically broadly applicable and applicable to the widest set of goals

Facilitate data sharing

Easy / understandable to apply

Can be used on a long term basis

Low environmental impact

$\begin{array}{llll}1 & 7 & 3\end{array}$

15

34

5

690

4

60

230

6

90

11

33

$\begin{array}{lll}6 & 66 & 4\end{array}$

44

222

$5 \quad 55$

2

4

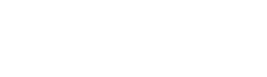

SUM

117

365

530

499

201

496 


\section{Figure Captions}

Figure 1. Demographics of standard sampling international symposium participants in the structured-decision-making workgroup at the discussion section of the AFS standard sampling symposium. All options that members of the group could select are on figure. 
Are you a member of AFS?

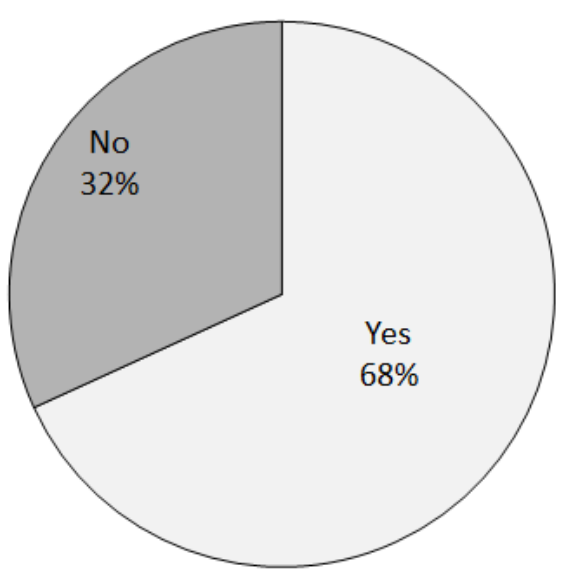

What best describes your position?

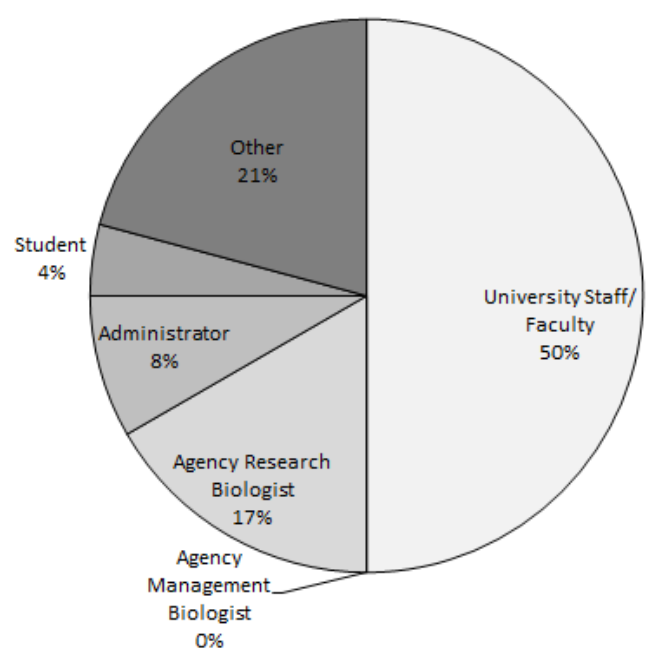

Figure 1.
On which continent do you do most of your inland (freshwater) fisheries work?

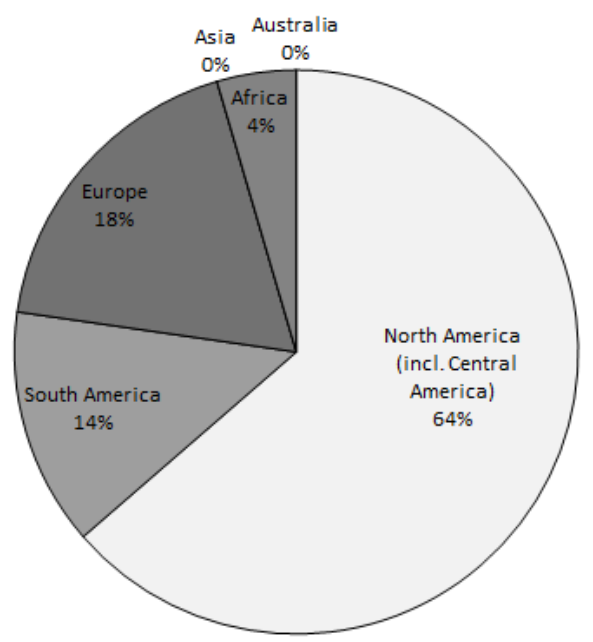

What best describes the organization for which you work?

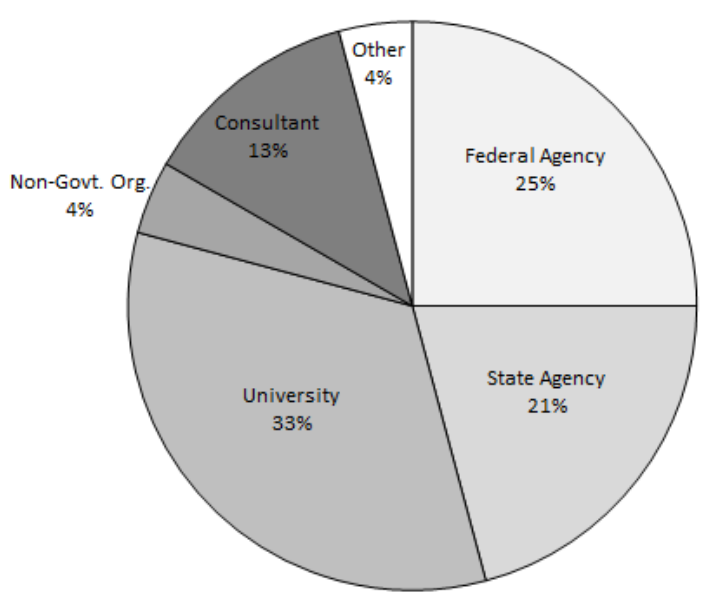

